\title{
Paedogobius kimurai, a New Genus and Species of Goby (Teleostei: Gobioidei: Gobiidae) from the West Pacific
}

\author{
Akihisa Iwata, ${ }^{1}$ SeIICHI Hosoya, ${ }^{2}$ AND Helen K. LARSON ${ }^{3}$ \\ ${ }^{1}$ Graduate School of Asian and African Area Studies, \\ Kyoto University, 46, Shimoadachi-cho, Yoshida, Sakyo-ku, Kyoto 606-8501, Japan \\ iwata@asafas.kyoto-u.ac.jp \\ ${ }^{2}$ Metocean Environment Inc., \\ Okinawa Branch, 2-24-3 Akebono, Naha, Okinawa 900-0002, Japan \\ seiiti@notes.metocean.co.jp \\ ${ }^{3}$ Museum and Art Gallery of the Northern Territory, \\ PO Box 4646, Darwin NT 0801, Australia \\ helen.larson@nt.gov.au
}

\begin{abstract}
Paedogobius kimurai, a new genus and species of Gobiidae, is described. This diandric genus is unique among the Gobiidae in having a long rod-shaped pelvis separated posteriorly into distinct left and right halves and no subpelvic process; and the ectopterygoid and quadrate widely separated in the secondary male. This genus is also distinguishable from the other genera of Gobiidae in having the following combination of characters: a maxillo-vomerine meniscus; the posteriormost soft dorsaland anal-fin pterygiophores each supporting an unbranched soft ray; 10 abdominal and 15 caudal vertebrae; the first one or two dorsal-fin pterygiophores inserting between the 9th and 10th neural spines; some sensory papillae on the branchiostegal region; and no first dorsal fin. Mature females (about $15 \mathrm{~mm} \mathrm{SL}$ ) have a transparent body with only a few melanophores, no pelvic fins, small jaws with a few minute teeth, and the nostrils formed into a single pit. Secondary males (about $16 \mathrm{~mm}$ SL) have pelvic fins, many melanophores especially on the head, and a robust head with large jaws armed with long canine-like teeth, and two nostrils. Primary males (about $12 \mathrm{~mm} \mathrm{SL}$ ), are smaller than females, and also have pelvic fins and two nostrils; however, the head is not robust, the small jaws are armed with a pair of short canine-like teeth and pigmentation is diffuse. This species is known from Japan, Thailand and northeastern Australia.
\end{abstract}

Iwata, Akinisa, Seitchi Hosoya \& Helen K. Larson, 2001. Paedogobius kimurai, a new genus and species of goby (Teleostei: Gobioidei: Gobiidae) from the west Pacific. Records of the Australian Museum 53(1): 103-112. 
The Gobioidei comprises about 270 nominal genera and 1,500-2,000 species (Hoese, 1984). Some gobioid genera have juvenile or larval-like characteristics when adult, with a transparent body and planktonic life mode. Examples of these are: the European genera Aphia Risso, Crystallogobius Gill and Pseudaphya Iljin; Grahamichthys Whitley from New Zealand; and the Indo-Pacific Gobiopterus Bleeker, Leucopsarion Hilgendorf, Rotuma Springer, Mistichthys Smith, and Tyson Springer. The Indo-Pacific fish Schindleria is perhaps the most larval-like, and is now known to be a gobioid (Johnson \& Brothers, 1993). Some of these small gobioid genera form schools hovering above the substrate (such as Gobiopterus and Mistichthys).

An unusual diandric goby not belonging to any of the above-mentioned paedomorphic genera was collected from coral reef and estuarine habitats in Japan, Thailand and Australia. We herein describe this species as a new genus and species of Gobiidae.

\section{Materials and methods}

Counts and measurements follow Nakabo (1993). Measurements were taken using a binocular microscope with an ocular micrometer, read to the nearest $0.1 \mathrm{~mm}$. Notation of the dorsal-fin pterygiophores and vertebrae (PV) follows Akihito et al. (1984). Vertebrae were counted from cleared and stained specimens prepared following the procedure of Dingerkus \& Uhler (1977).

Osteological observation were based on cleared and stained specimens. Terminology of osteology follows Gill \& Hoese (1993) and Johnson \& Brothers (1993). Cephalic sensory papillae were examined by staining the specimens with suminol cyanine. Catalogue abbreviations follow Leviton et al. (1985) except BLIH, Biological Laboratory, Imperial Household, Tokyo.

\section{Paedogobius n.gen.}

Type species. Paedogobius kimurai n.sp.

Diagnosis. Pelvis formed into long rod, extending posteriorly to vertical line through mid point of third abdominal vertebra. Left and right pelvic bones distinctly separated from each other posteriorly. Subpelvic process absent in both sexes. Ectopterygoid and quadrate widely separated in secondary male. Some sensory papillae present on branchiostegal membranes. Maxillo-vomerine meniscus present. First dorsal fin absent. Dorsal- and anal-fin pterygiophores each supporting one unbranched soft ray, with supernumerary ray on first pterygiophore of anal fin. Ten abdominal and fifteen caudal vertebrae. First one or two dorsal pterygiophores inserting between ninth and tenth neural spines.

Description. Data for holotype given first, followed by range and mode of paratype data in parentheses (see also Figs. 1-8 and Table 1).

Dorsal fin 14 (13-16, 14); anal fin $15(14-15,15)$; dorsaland anal-fin rays all unbranched, all segmented except anteriormost one and posteriormost one or two soft rays; pectoral fin $19(17-20,18)$; pelvic fin, if present, I,3 (I,3), rays unsegmented in primary male, second and third ray segmented in secondary male; upper and lower segmented caudal-fin rays $8+7(7-8+6-7,8+7)$; upper and lower branched caudal-fin rays $6+5(6+5-6,6+5)$; procurrent caudal rays in paratypes vii-x (ix; upper), viii-x (ix $=x$; lower); P-V 10 (10 or $9 \cdot 10,10)$; vertebrae $10+15=25$ $(10+15=25)$; scales totally absent.

Body strongly compressed and elongate. Eyes lateral. Mouth terminal to supraterminal, inclined obliquely upwards. First dorsal fin absent. Origin of second dorsal fin slightly posterior to vertical line through anus. Origin of anal fin beneath base of second ray of dorsal fin. Caudal fin slightly emarginate. Pectoral fin rounded. All rays except for some of caudal fin unbranched.

Sensory papillae on head in transverse pattern, some present on branchiostegal region (Figs. 6-8).

Maxillo-vomerine meniscus present. In secondary male, ectopterygoid and quadrate widely separated by unossified connective tissue. Pelvis a long rod. Left and right pelvic bones separated from each other posteriorly. Subpelvic process absent. Posteriormost dorsal- and anal-fin pterygiophore each supporting one unbranched soft ray.

Etymology. The generic name Paedogobius refers to the goby having a larval-like (paedomorphic) body.

New common name: Shirasukiba-haze-zoku (Japanese).

\section{Paedogobius kimurai n.sp.}

Figs. $1-8$, Table 1

Goby L-Miskiewicz, 1987: 113-116, 145, 147, figs. 4.33, 5.58, table 4.45.

Gobiid sp. 1 (wide-gape paedomorphic goby)—Neira \& Miskiewicz, 1998: 394-395, fig. 121a-f.

Type material. HOLOTYPE: NSMT-P52628, secondary ô, $14.8 \mathrm{~mm}$ (standard length), Amitori Bay $\left(24^{\circ} 19^{\prime} \mathrm{N}\right.$ $123^{\circ} 42^{\prime} \mathrm{E}$ ), Iriomote Island, Taketomi cho, Yaeyama gun, Okinawa Prefecture, Japan, 30 October 1994. PARATYPES: AMS I.37857-001, secondary $\delta, 14.2$, collection locality as for holotype, 31 October 1995; BLIH 1994022, secondary $\widehat{o}, 14.8$, same data as previous; FAKU 65770, secondary ot, 14.1, same data as previous; NTM S.14628001, secondary $\delta, 14.2$, same data as previous; USNM 344538 , secondary $\widehat{0}, 14.1$, same data as previous; NTM S.14596-001, secondary ot, 15.4, collection locality as for holotype, 10 July 1996; AMS I.37858-001, + , 15.2, Nakagusuku Bay $\left(26^{\circ} 12^{\prime} \mathrm{N} 127^{\circ} 50^{\prime} \mathrm{E}\right)$, Okinawa Island, Okinawa Prefecture, Japan, 29 May 1994; BLIH 1994025, $\uparrow, 15.5$, same data as previous; BLIH 1994026, secondary ô, 16.1, same data as previous; BMNH 1997.4.22:3, ㅇ, 15.7, same data as previous; NSMT-P52631,,+ 15.3 , same data as previous; USNM 344539 , $q, 14.3$, same data as previous; YCM-P33070, secondary $\delta, 16.4$, same data as previous; YCM-P33072, $\odot, 16.2$, same data as previous; 

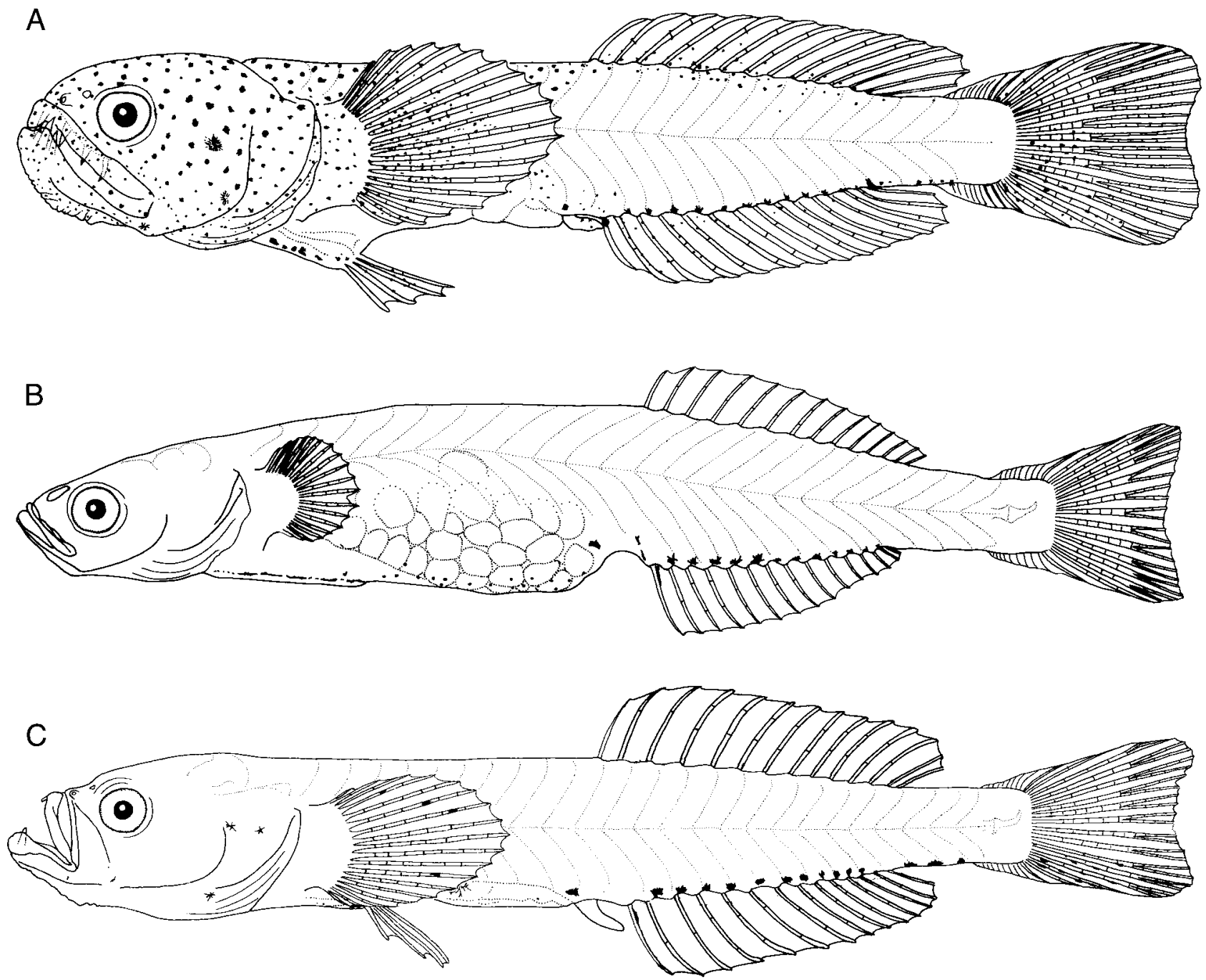

Figure 1. Paedogobius kimurai n.gen. and n.sp. A, holotype, NSMT-P52628, secondary đิ, 14.8 mm SL; B, paratype, NSMT-P52630,, , $15.2 \mathrm{~mm}$ SL, note ovarian eggs visible through body wall; C, paratype, NSMT-P52629, primary o, $12.0 \mathrm{~mm} \mathrm{SL}$.

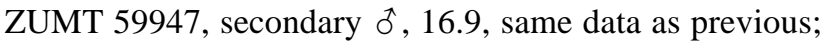
FAKU 65771, $q, 15.8$, collection locality as for AMS I.37858-001, 13 May 1994; YCM-P33071, ๆ, 14.8, same data as previous; ZUMT 59948, + , 15.7, same data as previous; BMNH 1997.4.22:2, secondary $\widehat{0}, 14.9$, collection locality as for AMS I.37858-001,30 May 1994; AMS I.37859-001, $९, 14.7$, collection locality as for AMS I.37858-001, 8 June 1994; BLIH 1994023, primary ô, 11.3, same data as previous; BLIH 1994024, + , 15.5, same data as previous; BMNH 1997.4.22:4, + , 14.7, same data as previous; FAKU 65769, primary $0,12.0$, same data as previous; FAKU 65772, + , 15.4, same data as previous; NSMT-P52629, primary ô, 12.0, same data as previous; NSMT-P52630, $q$, 15.2, same data as previous; USNM

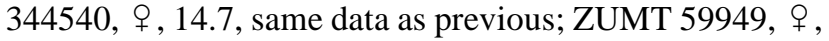
14.7, same data as previous; ZUMT 59950, primary $\hat{o}, 11.8$, same data as previous; NTM S.14595-001, , 14.4, collection locality as for AMS I.37858-001, 9 June 1994;

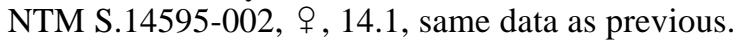

Non-type material. SIO 61-655, 5 ( 1 and 4 secondary ऽ。 $), 11.2,11.8-13.5$, Gulf of Thailand $\left(12^{\circ} 18.5^{\prime} \mathrm{N}\right.$ $\left.101^{\circ} 05.2^{\prime} \mathrm{E}\right)$, Thailand, 20 March 1960, Naga Expedition; AMS I.33290-005, 3 (all $\%$ \%), 10.2, 9.9 and 9.6, inshore of Pandora Reef, Queensland (18 $\left.49^{\prime} \mathrm{S} 146^{\circ} 26^{\prime} \mathrm{E}\right)$, Australia, 17-20 March 1983, collected by D. Williams; AMS I.33290006, 2 ( 1 secondary $\hat{o}$ and $1 \stackrel{q}{ }$ or primary $\hat{o}), 10.7,10.1$, collection locality and date as for AMS I.33290-005; BLIH 1985501 , + , 12.9, Hanejinaikai Bay $\left(26^{\circ} 39^{\prime} \mathrm{N} 128^{\circ} 01^{\prime} \mathrm{E}\right)$, Okinawa Island, Okinawa Prefecture, Japan, 17 October 1985; BLIH 1985502, $ๆ, 12.6$, same data as previous; BLIH 1986704, ㅇ, 6.9, same collection locality as previous, 20 November 1986; BLIH 1988350, ㅇ, 11.2, Itoman Bay $\left(26^{\circ} 07^{\prime} \mathrm{N} 127^{\circ} 39^{\prime} \mathrm{E}\right)$, Okinawa Island, Okinawa Prefecture, Japan, 3 June 1988; BLIH 1988351, + , 16.5, same collection locality as previous, 30 December 1988; BLIH 1989239 , + , 9.2, same collection locality as previous, 10 September 1989; BLIH 1989240, secondary ô, 14.6, same data as previous. 
Table 1. Proportional measurements in percent of standard length of Paedogobius kimurai n.gen. and n.sp.

\begin{tabular}{|c|c|c|c|c|}
\hline & \multicolumn{2}{|c|}{ secondary males } & \multirow{2}{*}{$\begin{array}{c}\text { primary males } \\
\text { paratypes } \\
\mathrm{N}=4\end{array}$} & \multirow{2}{*}{$\begin{array}{c}\text { females } \\
\text { paratypes } \\
\mathrm{N}=18\end{array}$} \\
\hline & $\begin{array}{c}\text { holotype } \\
\mathrm{N}=1\end{array}$ & $\begin{array}{c}\text { paratypes } \\
\mathrm{N}=8\end{array}$ & & \\
\hline total length & 118.2 & $115.5-120.6$ & $115.0-121.2$ & $112.5-118.4$ \\
\hline head length & 31.1 & 29.9-33.8 & $26.5-29.2$ & $22.7-25.2$ \\
\hline head depth at preopercular margin & 20.9 & $19.6-21.4$ & $15.3-16.7$ & $13.8-15.6$ \\
\hline body depth at pelvic-fin base & 23.0 & $18.9-23.6$ & $15.8-18.3$ & $15.1-18.4$ \\
\hline body depth at anal-fin origin & 16.9 & $14.9-16.6$ & $15.0-16.1$ & $15.0-17.0$ \\
\hline preanal length & 53.4 & $52.4-55.4$ & $52.2-55.0$ & $55.1-62.4$ \\
\hline snout length & 7.4 & $6.8-8.5$ & $5.9-7.5$ & $5.2-6.8$ \\
\hline head width at preopercular margin & 20.9 & $13.4-20.3$ & $12.4-14.2$ & $10.2-12.6$ \\
\hline body width at pectoral-fin base & 12.2 & $10.1-12.8$ & $8.8-10.2$ & $6.8-9.7$ \\
\hline body width at anal-fin origin & 6.1 & $5.9-7.1$ & $4.4-5.9$ & $5.0-6.5$ \\
\hline maxillary length & 18.2 & $15.9-19.1$ & $9.3-10.6$ & $5.2-9.8$ \\
\hline eye diameter & 6.1 & $4.7-6.5$ & $4.4-5.1$ & $4.4-5.7$ \\
\hline interorbital width & 8.8 & $8.8-11.3$ & $6.8-9.2$ & $4.8-7.8$ \\
\hline caudal peduncle length & 14.2 & $13.5-16.5$ & $13.6-18.3$ & $13.4-17.0$ \\
\hline caudal peduncle depth & 9.5 & $8.5-9.2$ & $7.5-8.5$ & $7.0-8.3$ \\
\hline longest pelvic-fin ray & 9.5 & $7.9-10.7$ & $6.8-11.7$ & absent \\
\hline longest pectoral-fin ray & 17.6 & $15.5-17.6$ & $13.6-18.6$ & $6.6-8.5$ \\
\hline second dorsal-fin base & 30.4 & $25.4-29.0$ & $28.8-29.2$ & $24.7-29.7$ \\
\hline anal-fin base & 27.4 & $23.9-28.4$ & $26.3-27.4$ & $22.8-28.4$ \\
\hline snout to second dorsal-fin origin & 54.7 & $56.7-59.2$ & $55.9-58.4$ & $57.6-63.2$ \\
\hline snout to second dorsal-fin end & 83.8 & $83.8-86.5$ & $83.9-86.7$ & $82.3-87.8$ \\
\hline snout to anal-fin origin & 56.8 & $57.3-60.6$ & $54.9-61.7$ & $57.8-62.1$ \\
\hline snout to anal-fin end & 81.8 & $82.5-85.8$ & $82.3-85.8$ & $82.9-87.8$ \\
\hline
\end{tabular}

Cleared and stained specimens (non type material). BLIH 1994032, primary ô, 11.7, BLIH 1994042, primary ô, 12.2, these with collection locality and date as for AMS I.37859001; BLIH 1994033 ㅇ 15.2, BLIH 1994034 secondary o 16.6, BLIH 1994035 secondary ơ 16.3, BLIH 1994036 우 16.3, BLIH 1994037 ㅇ 15.5, BLIH 1994038 오 14.3, these with collection locality and date as for AMS I.37858-001; BLIH 1994039 secondary ô 15.9, BLIH 1994040 secondary of 14.5, BLIH 1994041 o 14.1 , these with collection locality and date as for BMNH 1997.4.22:2; BLIH 1995033, secondary $\widehat{\delta}, 14.8$, collection locality as for holotype, 30 October 1995; BLIH 1995034, secondary ô, 14.8, same data as previous; BLIH 1989238, o, 6.6, collection locality and date as for BLIH 1989239.

Diagnosis. See generic diagnosis.

Description. Counts-See generic description. Measurements - data for range of paratypes (except BLIH 1994026 and BMNH 1997.4.22:2) given first, followed by holotype data in parentheses.

Female. Body depth at pelvic-fin base 5.4-6.6 in SL, body depth at anal-fin origin 5.9-6.7 in SL, body width at pectoral-fin base 10.3-14.7 in SL, body width at anal-fin origin 15.5-20.1 in SL, head length 4.0-4.4 in SL, head width at preopercular margin 1.2-1.5 in head depth at preopercular margin, snout length 3.7-4.8 in head length, eye diameter $4.5-5.3$ in head length.

Primary male. Body depth at pelvic-fin base 5.5-6.3 in SL, body depth at anal-fin origin 6.2-6.7 in SL, body width at pectoral-fin base 9.8-11.3 in SL, body width at anal-fin origin 16.9-22.6 in SL, head length 3.4-3.8 in SL, head width at preopercular margin 1.2-1.3 in head depth at preopercular margin, snout length 3.9-4.3 in head length, eye diameter 5.3-6.0 in head length.

Secondary male. Body depth at pelvic-fin base 4.2-5.3 (4.4) in SL, body depth at anal-fin origin 6.0-6.7 (5.9) in SL, body width at pectoral-fin base 7.8-9.9 (8.2) in SL, body width at anal-fin origin 14.1-16.9 (16.4) in SL, head length 3.0-3.3 (3.2) in SL, head width at preopercular margin 1.0 1.5 (1.0) in head depth at preopercular margin, snout length 3.8-4.5 (4.2) in head length, eye diameter 5.0-6.4 (5.1) in head length.

Head and body shape. Female. Head strongly compressed. Nostril a single shallow pit. Dorsal profile from nape to origin of dorsal fin slightly convex. Maxilla extends to 

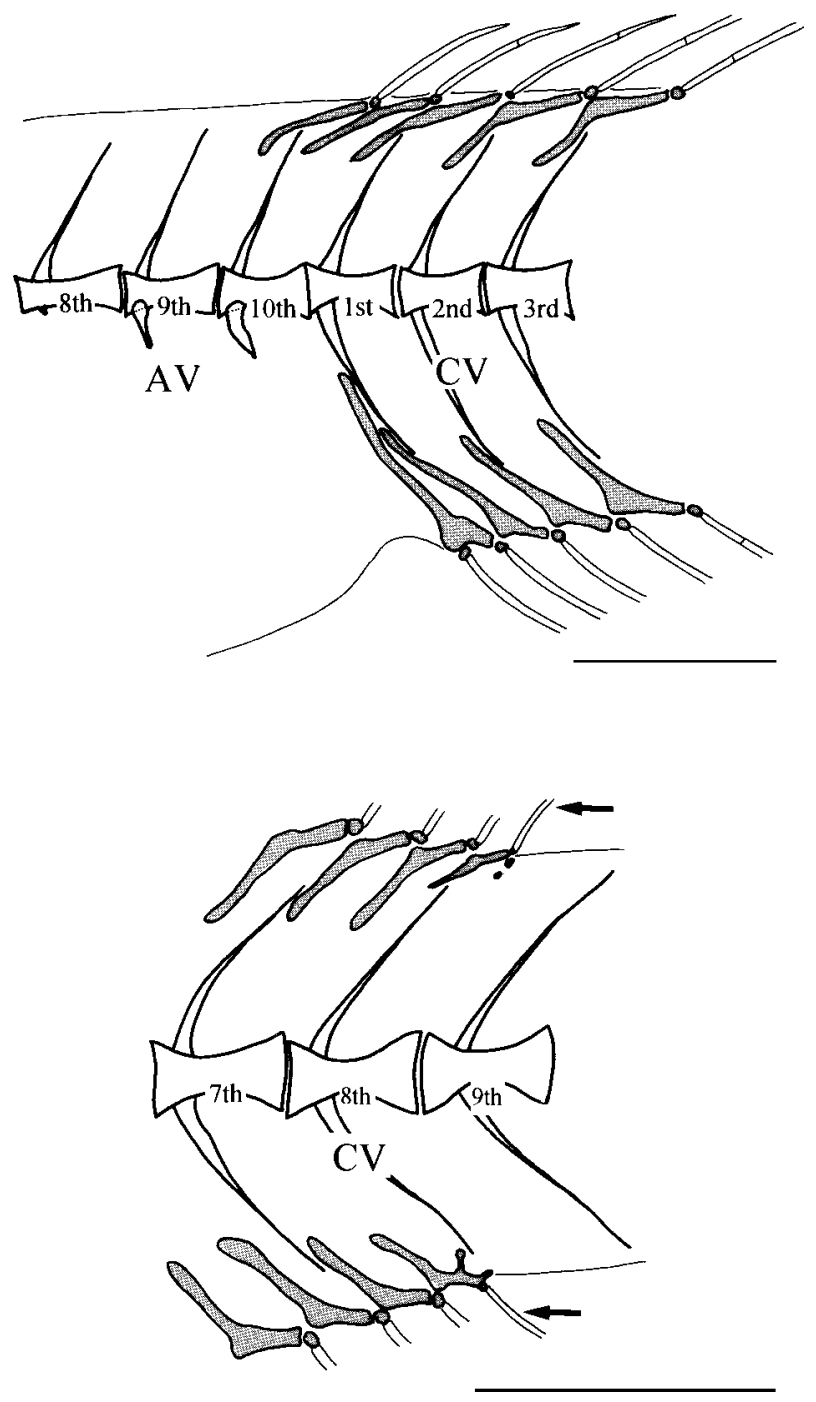

Figure 2. Vertebrae, and anterior and posterior parts of dorsaland anal-fin of Paedogobius kimurai (ㅇ, BLIH 1994033). Abbreviations: AV, abdominal vertebrae; $\mathrm{CV}$, caudal vertebrae. Arrows indicate unbranched last dorsal and anal soft rays. Scale bars are $1 \mathrm{~mm}$. Shading = cartilage or unossified bone.

below front of eye. Lower jaw prominent. Upper and lower jaw with series of small conical teeth. Anteroventral margin of gill opening reaching to point below posterior end of pupil, lower end of branchiostegal membranes attaching at middle point of isthmus. Urogenital papilla absent. Pectoral fin small, posterior tip slightly anterior to vertical line through posterior end of pelvis. Pelvic fin absent. Posterior ends of dorsal and anal fins widely separated from upper and lower origin of caudal fin. Upper and lower ends of caudal fin weakly pointed. Ovary visible in abdomen through transparent body. Upper half of quadrate and pelvis unossified.

Primary male. Head strongly compressed. Two nostrils present, anterior with short tube. Dorsal profile, from nape to origin of dorsal fin, almost straight. Maxilla extends to
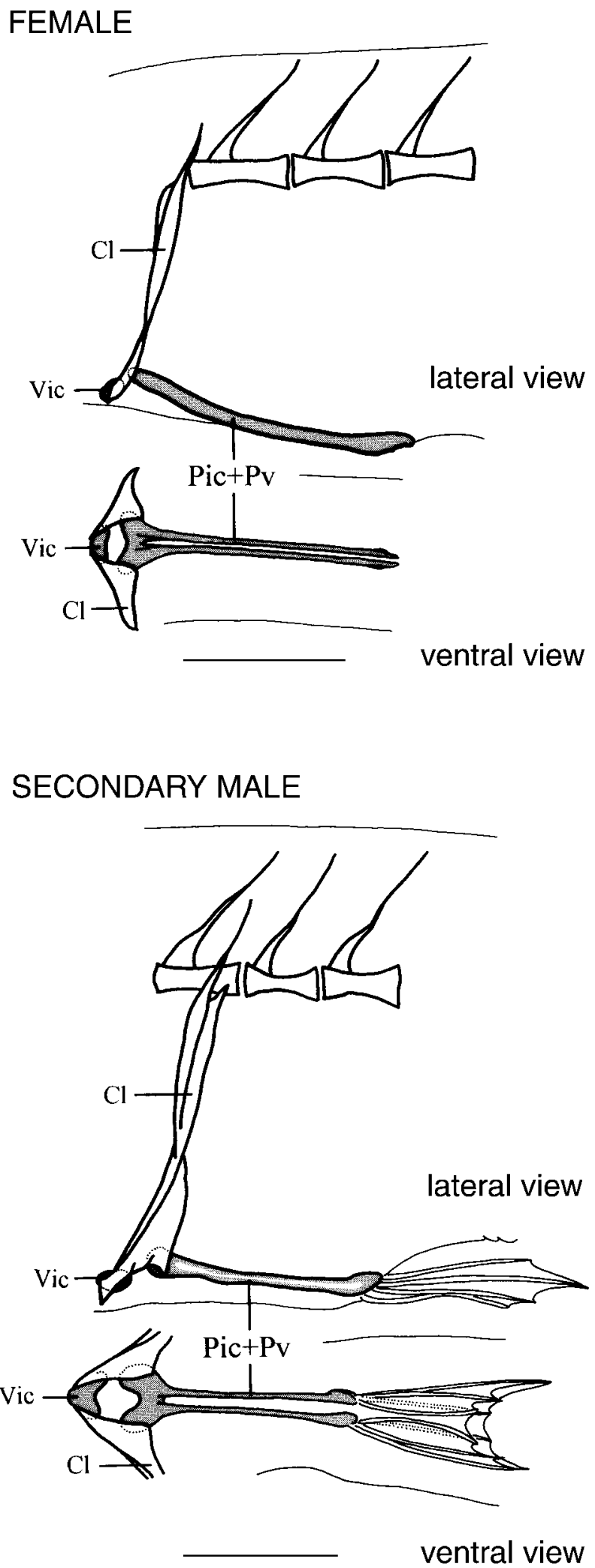

Figure 3. Lateral and ventral view of left pectoral and pelvic girdles of Paedogobius kimurai ( 9 , BLIH 1994033; secondary $\widehat{o}$, BLIH 1994034). Abbreviations: Cl, cleithrum; Pic + Pv, pelvic intercleithral cartilage and pelvis; Vic, ventral intercleithral cartilage. Scale bars are $1 \mathrm{~mm} . \mathrm{h}$ 


\section{FEMALE}

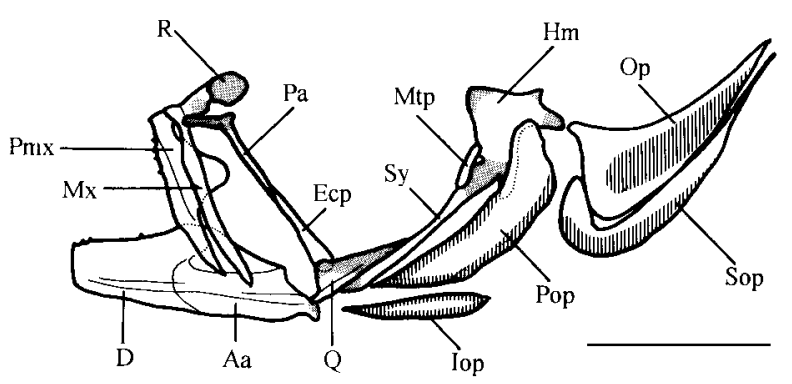

\section{PRIMARY MALE}

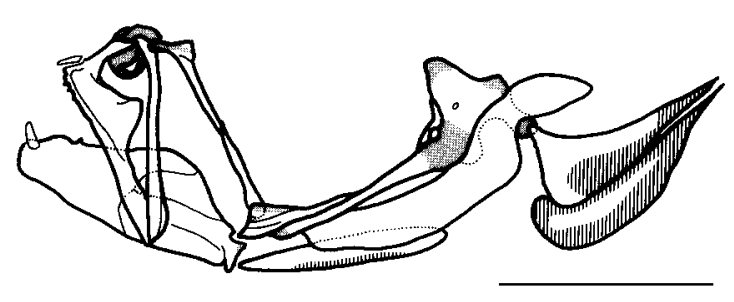

\section{SECONDARY MALE}

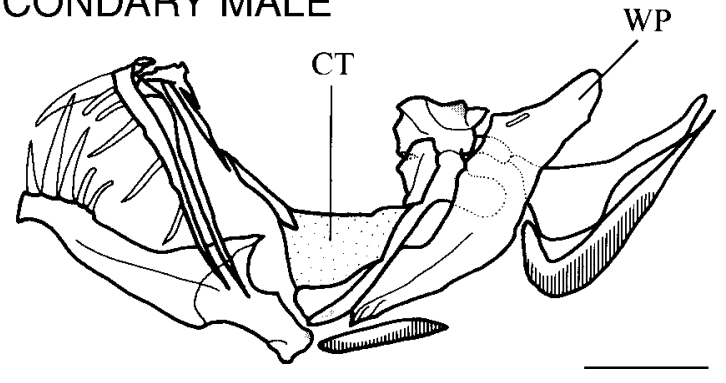

Figure 4. Left lateral view of jaws and suspensorium of Paedogobius kimurai ( 9 , BLIH 1994033; primary ô, BLIH 1994032; secondary đo, BLIH 1994034). Abbreviations: Aa, anguloarticular; CT, connecting tissue; D, dentary; Ecp, ectopterygoid; Hm, hyomandibula; Iop, interopercle; Mtp, metapterygoid; Mx, maxilla; Op, opercle; Pa, palatine; Pmx, premaxilla; Pop, preopercle; Q, quadrate; R, rostral; Sop, subopercle; Sy, symplectic; WP, wing-like projection of preoperculum. Ossified rostral of secondary $\widehat{0}$ hidden by maxilla and premaxilla. Scale bars are $1 \mathrm{~mm}$. Shading = cartilage; stippling $=$ connective tissue; striping $=$ decalcified area.

below front part of eye. Five and two conical teeth across front of upper and lower jaws respectively, anteriormost tooth of both jaws largest. Anteroventral margin of gill opening reaches point below anterior end of pupil, lower end of branchiostegal membranes attach at middle point of isthmus. A slender urogenital papilla present, curving backward. Pectoral fin of moderate size, posterior tip reaches to vertical line through mid point between origins of pelvic and anal fins. Pelvic fin present with complete
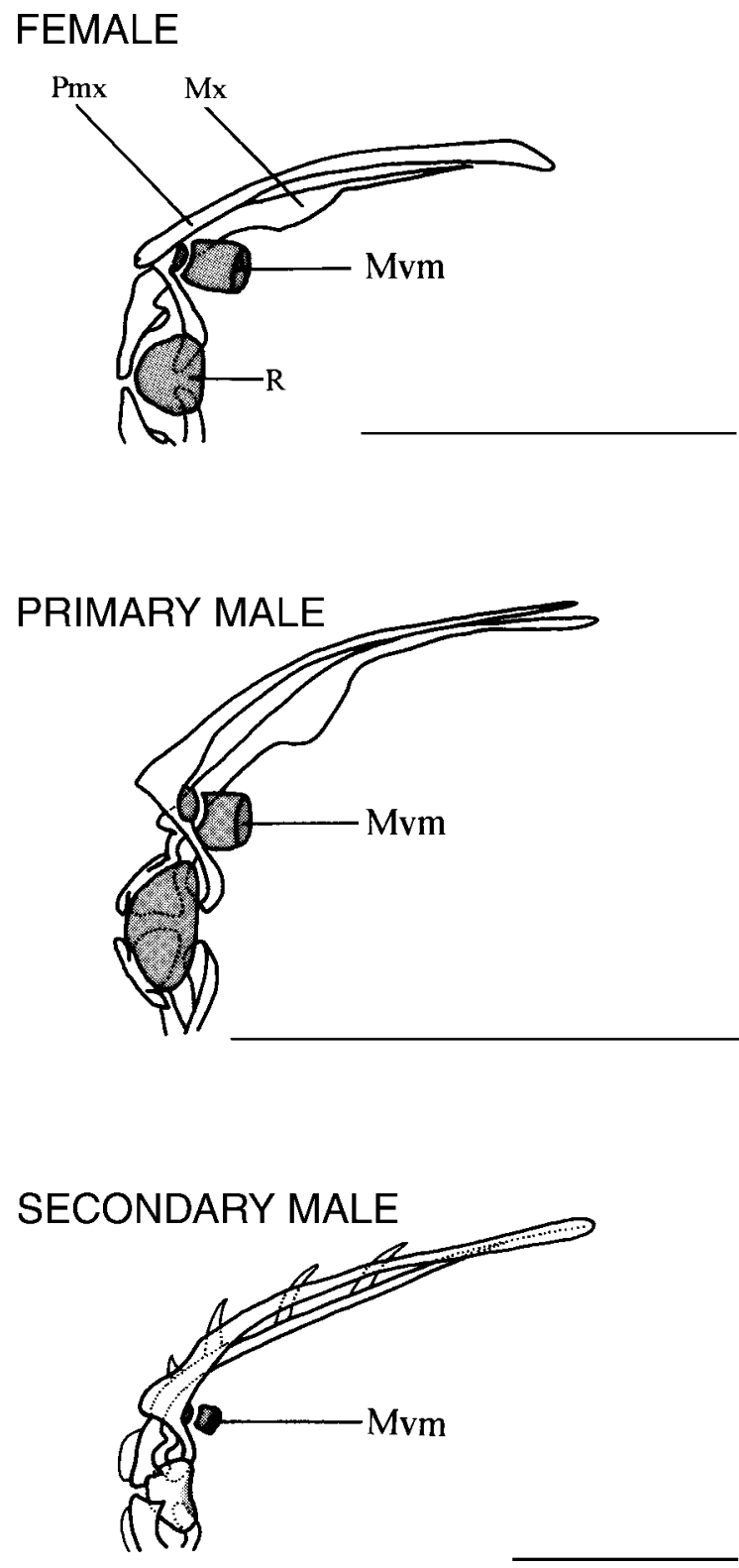

Figure 5. Dorsal view of rostral and right upper jaws of Paedogobius kimurai ( 9 , BLIH 1994033; primary o, BLIH 1994032; secondary ô, BLIH 1994034). Abbreviations: Mvm, maxillo-vomerine meniscus; Mx, maxilla; Pmx, premaxilla; R, rostral. Scale bars are $1 \mathrm{~mm}$. Shading = cartilage.

frenum and connecting membrane between third rays, forming long disc; when appressed, posterior end reaches midpoint between origin of pelvic fin and anus. Posterior ends of dorsal and anal fins widely separated from upper and lower origin of caudal fin. Upper and lower margins of caudal fin weakly rounded. Cartilaginous area on anterior part of quadrate narrow. Posterior two-thirds of pelvis weakly ossified laterally. 
Secondary male. Head large, rounded, slightly compressed, temporal region may be inflated. Two nostrils present, anterior with short tube. Dorsal profile, from nape to origin of dorsal fin, almost straight. Anterior margin of upper jaw with concavity on each side, behind jaw tip, and anterior margin of lower jaw with convexity on each side. Maxilla extends beyond rear of eye. Upper jaw with single series of six large canine-like teeth on each side, anteriormost largest, second and third smaller, with blunt tips. Lower jaw with series of five large canine-like teeth on each side, concentrated on anterior part of jaw, second largest, fourth and fifth have blunt tip, one tooth with blunt tip present just behind anteriormost tooth (hidden by second large tooth in Fig. 4). Anteroventral margin of gill opening reaches to point below halfway between posterior end of eye and preopercle, lower end of branchiostegal membranes attaches at middle point of isthmus. A slender, elongate urogenital papilla present, curving backward. Pectoral fin large, posterior end reaches to vertical line through anus. Pelvic fin present with complete frenum and connecting membrane between third rays, forming long disc, posterior end reaches to mid-point between origin of pelvic fin and anus. Posterior ends of dorsal and anal fins widely separated from upper and lower origin of caudal fin. Upper and lower margins of caudal fin rounded. Rostral cartilage and quadrate ossified (Fig. 5). Pelvis weakly ossified laterally. A large wing-like projection present on upper posterior end of preopercle.

Cephalic lateral line system. Description of cephalic lateral line system based on the following specimens: $q$, BLIH 1994024; primary ô, BLIH 1994023; secondary ô, BLIH 1994026.

Female. Sensory canal and canal pore absent. Two longitudinal papillae rows on dorsal surface of snout. A broken transverse papillae row across interorbital. A long transverse papillae row across anterior occiput. Two short, longitudinal papillae rows on posterior occiput. Two short, transverse papillae rows on dorsolateral side of posterior occiput. Two longitudinal and one transverse papillae rows on side of snout anterior to eye. Three transverse papillae rows on cheek below eye. Two short, longitudinal papillae rows containing two papillae directly behind eye. A pair of longitudinal papillae rows on chin. Two papillae on branchiostegal region. One to several papillae around nostril, on both sides of interorbital, cheek, operculum, and along lower edge of preopercle and lower jaw, sometimes forming short rows.

Primary male. Sensory canal and canal pore absent. Two or three pairs of longitudinal papillae rows on dorsal surface of snout. A long transverse papillae row across interorbital. A long, transverse papillae row across anterior occiput. Two short, transverse papillae rows on dorsolateral side of anterior occiput. Two longitudinal papillae rows on posterior occiput. Two short, transverse papillae rows on dorsolateral side of posterior occiput. Longitudinal, diagonal and transverse papillae rows on side of snout anterior to eye. Five transverse diagonal papillae rows on cheek below and behind of eye. Two longitudinal papillae rows on chin. Three
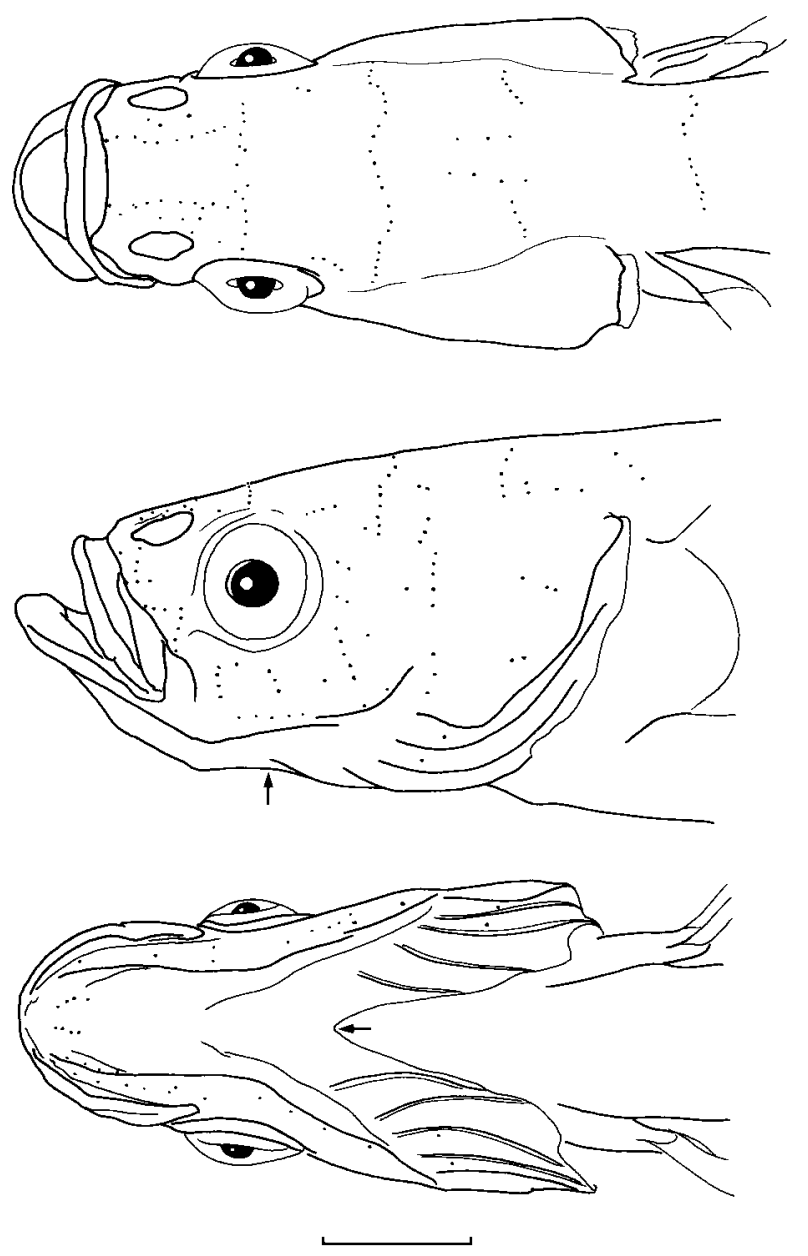

Figure 6. Cephalic lateral line system of dorsal, lateral, and ventral side of female of Paedogobius kimurai, BLIH 1994024 (15.5 mm SL). Dots represent the sensory papillae; and the arrow points to where the gill membranes attach to the isthmus. Scale bar $1 \mathrm{~mm}$.

papillae on branchiostegal region. One to several papillae around nostrils, on each side of interorbital, nape, cheek, operculum, and along lower edge of preopercle and lower jaw, sometimes forming short rows.

Secondary male. Sensory canal and canal pore absent. Two longitudinal papillae rows on dorsal surface of snout with two transverse rows between them. A broken transverse papillae row on interorbital. A long, transverse papillae row across anterior occiput. Two short, transverse papillae rows on dorsolateral side of anterior occiput. Two longitudinal papillae rows on posterior occiput. Two short, transverse papillae rows on dorsolateral side of posterior occiput. Three diagonal or transverse papillae rows on side of snout anterior to eye. Five transverse or diagonal papillae rows on cheek below and behind eye. Two longitudinal papillae rows on chin. Three papillae on branchiostegal region. One to several papillae around nostrils, on each side of interorbital, nape, cheek, operculum, and along lower edge of preopercle and lower jaw, sometimes forming short rows. 

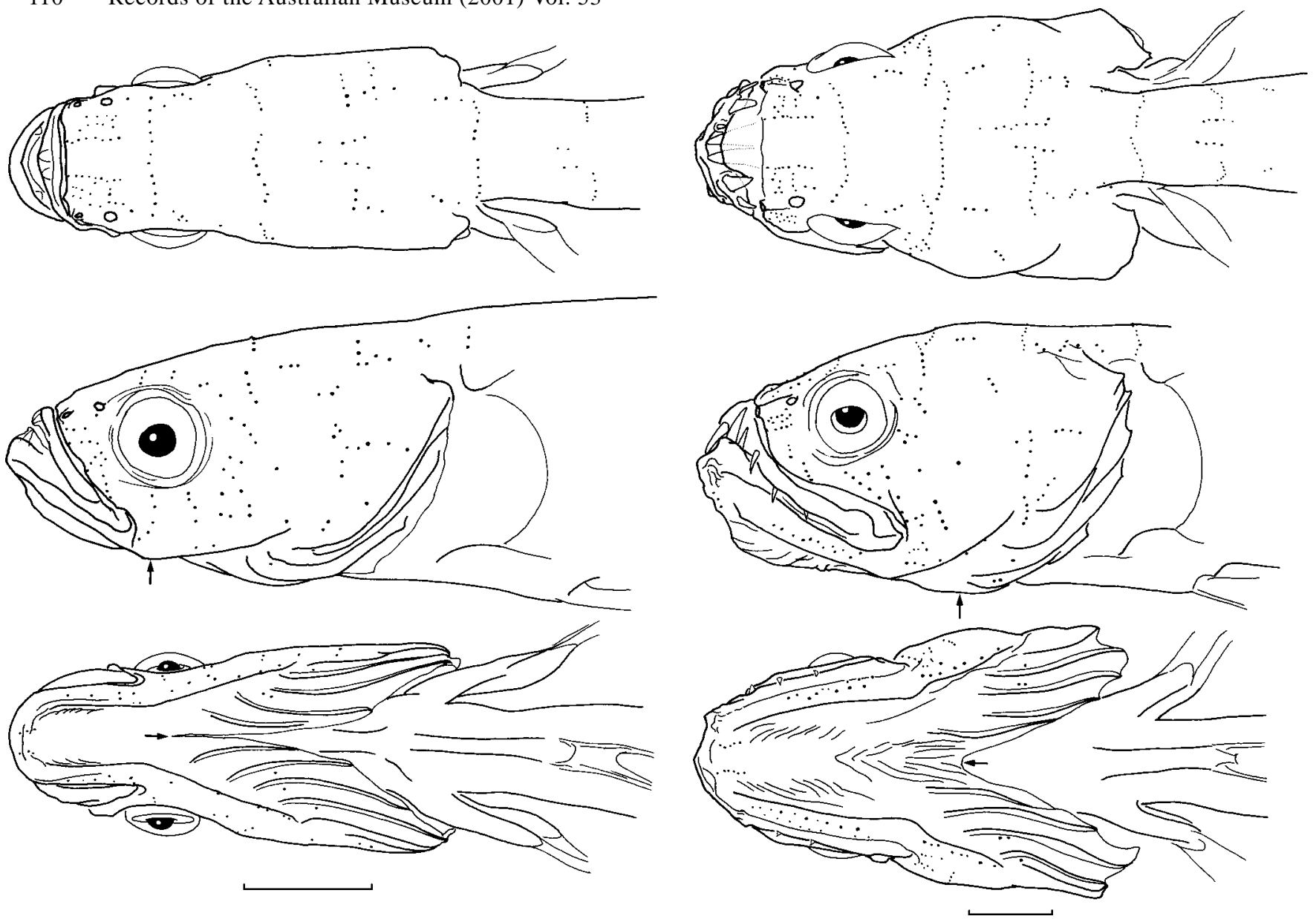

Figure 7. Cephalic lateral line system of dorsal, lateral, and ventral side of primary male of Paedogobius kimurai, BLIH 1994023 (11.3 mm SL). Dots represent the sensory papillae; and the arrow points to where the gill membranes attach to the isthmus. Scale bar is $1 \mathrm{~mm}$.

Coloration. Female. A row of melanophores along anal-fin base, also on ventral midline of lower edge of caudal peduncle in some individuals. An elongate melanophore along upper rear edge of first anal-fin ray. Single melanophore on inner side of upper part of anus; one or two melanophores on inner side of posterodorsal part of anus in some individuals. Many small granule-like melanophores on ventral surface of abdomen. A row of melanophores on inner side of pelvis. Several melanophores on lower half of caudal-fin rays, near base, in some individuals. Peritoneum unpigmented. Anterodorsal portion of swim-bladder pigmented, with dendritic melanophores.

Primary male. A row of melanophores on anal-fin base and ventral midline of lower edge of caudal peduncle. An elongate melanophore along upper rear edge of first anal ray. A melanophore on inner side of upper part of anus. Two dendritic melanophores on testis (one hidden by pectoral fin in Fig. 1). A row of melanophores on inner side of pelvis. Several melanophores on lower half of caudalfin rays, near base. Several melanophores on some pectoralfin rays. Two small dendritic melanophores on operculum, and one on branchiostegal region. Peritoneum unpigmented.

Figure 8. Cephalic lateral line system of dorsal, lateral, and ventral side of secondary male of Paedogobius kimurai, BLIH 1994026 (16.1 mm SL). Dots represent the sensory papillae; and the arrow points to where the gill membranes attach to the isthmus. Scale bar is $1 \mathrm{~mm}$.

Anterodorsal portion of swim-bladder pigmented, with dendritic melanophores.

Secondary male. A row of melanophores on anal-fin base and ventral midline of lower edge of caudal peduncle. Many melanophores on caudal-fin rays near base, on lower half of dorsal and anal fins, on anterior half of pectoral fin and posterior part of pelvic fin. Some melanophores on urogenital papilla. Many melanophores on body, with largest on the anterior half, especially on head. Peritoneum unpigmented. Anterodorsal portion of swim-bladder pigmented, with dendritic melanophores.

Distribution. Australia (New South Wales and Queensland), Botany Bay $\left(34^{\circ} 00^{\prime} \mathrm{S} 151^{\circ} 11^{\prime} \mathrm{E}\right)$, Hawkesbury River ( $\left.33^{\circ} 30^{\prime} \mathrm{S} 151^{\circ} 10^{\prime} \mathrm{E}\right)$, Lake Macquarie $\left(33^{\circ} 05^{\prime} \mathrm{S}\right.$ $\left.151^{\circ} 35^{\prime} \mathrm{E}\right)$, Pandora Reef $\left(18^{\circ} 49^{\prime} \mathrm{S} 146^{\circ} 26^{\prime} \mathrm{E}\right)$ (after Neira \& Miskiewicz, 1998); ThaILAND, Gulf of Thailand $\left(12^{\circ} 18.5^{\prime} \mathrm{N} 101^{\circ} 05.2^{\prime} \mathrm{E}\right)$; JAPAN, Hanejinaikai Bay $\left(26^{\circ} 39^{\prime} \mathrm{N} 128^{\circ} 01^{\prime} \mathrm{E}\right)$, Itoman Bay $\left(26^{\circ} 07^{\prime} \mathrm{N} 127^{\circ} 39^{\prime} \mathrm{E}\right)$ and Nakagusuku Bay $\left(26^{\circ} 12^{\prime} \mathrm{N} 127^{\circ} 50^{\prime} \mathrm{E}\right)$ at Okinawa Island, Amitori Bay $\left(24^{\circ} 19^{\prime} \mathrm{N} 123^{\circ} 42^{\prime} \mathrm{E}\right)$ at Iriomote Island. 
Etymology. The specific epithet, kimurai, is for $\mathrm{Mr}$ Motofumi Kimura, who first discovered this species in Japan.

Common names: Wide-gape paedomorphic goby (English) or Shirasukiba-haze (Japanese).

\section{Discussion}

The differences in head and body shapes between the female and secondary male Paedogobius are striking. However, unquestionable evidence as to the species' identification exists; under aquarium conditions, females, about one week after spawning, undergo a change in form to became secondary males. The females reared in captivity were collected in Nakagusuku Bay using Shirasu-Patch net, a kind of specialised net used in a fishery for juvenile sardines. All fishes collected by this net died, apart from those individuals used in the aquarium experiment, which were got to the laboratory quickly by sorting on them on-board. No male was present among the captive fish used in the experiment. The females were fed live Artemia and spawned in the aquarium two or three days after collection. A mass of 27 eggs was studied. The eggs formed a single mass, tangled together by a series of filaments arising from the basal part of each egg. The eggs were long and ellipsoid, $2.6-2.8 \mathrm{~mm}$ and $0.5 \mathrm{~mm}$ in long and short axes, respectively. These eggs did not develop because they were not fertilized.

The second author continued rearing the same captive females in the same aquarium. The females changed head and body shape, pelvic fins developed gradually, and the fish developed into secondary males about one week after spawning. Accordingly, it is apparent that the females changed sex after spawning. In addition, the changing process (accompanying maturity from immature male to primary male), as well as the sex change from female to secondary male, was observed in many specimens collected from Nakagusuku Bay, Okinawa Island, Japan. Both primary and secondary males possess ripe sperm (Dr A. Hattori, pers. comm.).

Paedogobius kimurai differs from all known genera of Gobiidae in having a characteristic pelvis shape, and a unique widely separated ectopterygoid and quadrate in the secondary male. Additionally, there has been no previous verified report of sex-change in the broad group to which Paedogobius belongs, the Gobionellinae (Dr Kassi Cole, pers. comm.).

Johnson \& Brothers (1993) included Schindleria in the Gobioidei. Paedogobius shares some characters with Schindleria, including a maxillo-vomerine meniscus, one unbranched ray supported by the last pterygiophore of the dorsal and anal fin, and a transparent body. However, it differs from the latter in a number of ways, such as having a pelvis, a urostyle similar to second preural centrum in length, fewer vertebrae, and in the deeper body.

Paedogobius belongs in the Gobiopterus group sensu Birdsong et al. (1988) (Brachygobius, Gobiopterus, Mistichthys, Pandaka) in having a 10+15 vertebral count and a similar geographic distribution. The general appearance of male Gobiopterus bears some resemblance to the secondary males of Paedogobius, in having a rounded robust head, large canine-like teeth in both jaws and transverse sensory papillae. Larson (in press) discusses the relationships of this group, stating that Brachygobius and Pandaka are sister-taxa (and are related to Stigmatogobius and Mugilogobius). Gobiopterus and Mistichthys share several characters with Brachygobius and Pandaka: all segmented rays in second dorsal and anal fins, $10+15$ vertebrae, two anal-fin pterygiophores inserting before the first caudal vertebra, and one or two, usually two, epurals. Brachygobius and Pandaka differ from the transparent larval-like Gobiopterus and Mistichthys in their conspicuous banded or spotted black and white colour patterns.

Paedogobius bears some resemblance (especially secondary males) to Gobiopterus and Mistichthys, which are also dwarf, paedomorphic gobiids. Neither genus has been reviewed or clearly diagnosed in the literature, but these taxa are presently being revised by the third author. Some preliminary diagnostic information is provided here, based on observations of eight species of Gobiopterus and the single nominal species of Mistichthys (opinions of third author).

Mistichthys is considered as monotypic (M. luzonensis Smith), known only from Lake Buhi, Luzon, in the Philippines. There is little sexual dimorphism in adult size and none in tooth form: both sexes have a single row of small, fine, pointed teeth in each jaw; there are II-IV first dorsal-fin rays, the gill opening is wide and may reach to posterior edge of eye; scales are present on the body, and the jaws are terminal, oblique, but not nearly vertical.

Gobiopterus includes about 14 nominal species, all of which appear to be sexually dimorphic (males and females have been described as separate species), known from brackish lakes, estuaries and mangroves in the Indo-West Pacific. Gobiopterus males may be larger than females and have enlarged, flattened, caniniform teeth (teeth small, sharp and evenly sized in females). These fish have III-V (usually V) first dorsal-fin spines, the gill opening is variable, from below the opercle to halfway between preopercular margin and the posterior edge of the eye; the jaws are strongly oblique to nearly vertical in large males; and scales are usually present.

Paedogobius differs from these two genera in lacking a first dorsal fin (present in Gobiopterus and Mistichthys), having I,3 pelvic-fin rays (I,5 in Gobiopterus and Mistichthys), a greater number of fin rays (13-16 second dorsal-fin rays versus 7-9 in Gobiopterus and Mistichthys), a wide gill opening which varies from under mid-eye in female and primary male and under preopercle in secondary male (gill opening to at least rear margin of eye in Mistichthys and under opercle or preopercle in Gobiopterus), lacking scales (scale cover present in varying degrees in Gobiopterus and Mistichthys), and different pelvis form.

The rod-like pelvis shape in Paedogobius is similar to that of Gobiopterus and its relative Mistichthys. The pelvis in these genera, however, differs from that of Paedogobius in the following characters: pelvis shorter, not extending past vertical line through posterior end of second abdominal vertebra in Gobiopterus, may just reach past posterior end of second vertebra in Mistichthys (vs extending to vertical line through mid point of third abdominal vertebra in 
Paedogobius); subpelvic process present in males (vs absent in both sexes) and posterior ends of left and right pelvic bones almost attached or attached to each other (vs posterior ends always clearly separated from each other).

Separation of the ectopterygoid and quadrate is unusual among gobiids, being found only in the secondary male of this genus. Also, the secondary male can open its mouth a full $180^{\circ}$. The separation of ectopterygoid and quadrate makes this possible, along with the strong adductor mandibulae muscles which attach posteriorly to a large, wing-like dorsal projection of the preopercle (Figs. 4 and 9). Although their wide jaws and teeth resemble that of secondary male Paedogobius, large adult male Gobiopterus possess a preopercle resembling that of a female Paedogobius and the jaws cannot be gaped so widely.

Miskiewicz (1987) and Neira \& Miskiewicz (1998) describe and illustrate the larval stages of this species. The pigment along the ventral mid-line of the caudal peduncle and the teeth form early in development.

ACKNOWLEDGMENTS. We are grateful to Mr Motofumi Kimura of Okinawa Prefectural Fisheries Experiment Station, Dr Tetsushi Senta of Nagasaki University, and Dr Tetsuhisa Noichi, of the Natural History Museum and Institute, Chiba, who entrusted us with this study. We wish to thank Dr Jeffrey M. Leis, Australian Museum, for bringing the Thai specimens to our attention and Dr Francisco J. Neira, Victorian Fisheries Research Institute, for provision of useful information. Our thanks to His Majesty Emperor Akihito, and Messrs Katsusuke Meguro, Katsuichi Sakamoto and Yuuji Ikeda, Imperial Household, for offering us time for the study. Thanks are also offered to Mr Shigeo Tabata, Metocean Environment Inc., for collection assistance, and to Dr Akihisa Hattori, Shiga University, for observations of reproductive tissue.

\section{References}

Akihito, Prince, M. Hayashi, T. Yoshino, K. Shimada, T. Yamamoto \& H. Senou, 1984. Suborder Gobioidei. In The Fishes of the Japanese Archipelago (plates and English text), eds. H. Masuda, K. Amaoka, C. Araga, T. Uyeno and T. Yoshino, pp. 236-289, pls. 235-258, 353-355. Tokyo: Tokai University Press.

Birdsong, R.S., E.O. Murdy \& F.L. Pezold, 1988. A study of the vertebral column and median fin osteology in gobioid fishes with comments on gobioid relationships. Bulletin of Marine Science 42(2): 174-214.

Dingerkus, G., \& L.D. Uhler, 1977. Enzyme clearing of alcian blue stained whole small vertebrates for demonstration of cartilage. Stain Technology 52: 229-232.

Gill, A.C., \& D.F. Hoese, 1993. Paraxenisthmus springeri, new genus and species of gobioid fish from the West Pacific, and its phylogenetic position within the Xenisthmidae. Copeia 1993(4): 1049-1057.

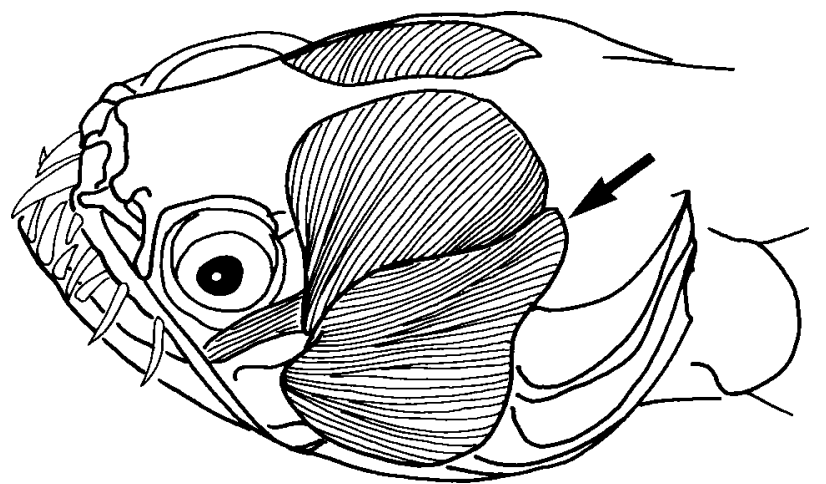

Figure 9. Adductor mandibulae muscles in BLIH 1995033 (14.8 $\mathrm{mm} \mathrm{SL}$ ). Arrow points to posterior attachment on wing-like projection of preoperculum.

Hoese, D.F., 1984. Gobioidei: relationships. In Ontogeny and Systematics of Fishes-An International Symposium Dedicated to the Memory of Elbert Halvor Ahlstrom, eds. H.G. Moser, W.J. Richards, D.M. Cohen, M.P. Fahay, A.W. Kendall Jr. and S.L. Richardson, pp. 588-591. 15-18 August 1983, La Jolla, California, American Society of Ichthyologists and Herpetologists Special Publication 1, Gainesville, Florida.

Johnson, G.D., \& E.B. Brothers, 1993. Schindleria: a paedomorphic goby (Teleostei: Gobioidei). Bulletin of Marine Science 52(1): 441-471.

Larson, H.K., in press. A revision of the gobiid fish genus Mugilogobius (Teleostei: Gobioidei), with discussion of its systematic placement. Records of the Western Australian Museum, Supplement.

Leviton, A.E., R.H. Gibbs Jr., E. Heal \& C.E. Dawson, 1985. Standards in herpetology and ichthyology. Part I. Standard symbolic codes for institutional resource collection in herpetology and ichthyology. Copeia 1985: 802-832.

Miskiewicz, A.G., 1987. Taxonomy and ecology of fish larvae in Lake Macquarie and New South Wales coastal waters. PhD thesis, University of New South Wales, Sydney.

Nakabo, T., 1993. Morphological characteristics and taxonomic characters. In Fishes of Japan with Pictorial Keys to the Species, ed. T. Nakabo, pp. x-xix. Tokyo: Tokai University Press. [In Japanese]

Neira, F.J., \& A.G. Miskiewicz, 1998. Gobiid sp. 1. In Larvae of Temperate Australian Fishes. Laboratory Guide for Larval Fish Identification, eds. F.J. Neira, A.G. Miskiewicz and T. Trnski, pp. 394-395. University of Western Australia Press, Nedlands, WA.

Manuscript received 3 June 2000, revised 19 October 2000 and accepted 1 November 2000

Associate Editor: J.M. Leis. 